\title{
Pancreatic enzyme deficiency depends on dietary protein origin in milk-fed calves
}

\author{
P. Guilloteau, ${ }^{\star 1}$ M. Plodari, ${ }^{*}$ V. Romé, ${ }^{*}$ G. Savary, ${ }^{*}$ L. Le Normand, ${ }^{*}$ and R. Zabielski† \\ *INRA, UMR 1079, Système d'Elevage, Nutrition Animale et Humaine (SENAH), Domaine de la Prise, 35590 Saint-Gilles, France \\ †Department of Physiological Sciences, Faculty of Veterinary Medicine, Warsaw University of Life Sciences, 02-766 Warsaw, Poland
}

\begin{abstract}
In young mammals, milk proteins and their substitutes are used in milk formula. Protein substitution modifies diet digestibility and pancreatic secretions. The aim of this study was to test if milk protein substitution could generate pancreatic deficiency in milk-fed calves. The effect of pancreatic juice on the digestibility of proteins was studied. Measurement of apparent fecal nutrient digestibility was used to estimate digestion. Ten calves (60 to $130 \mathrm{~d}$ old) were chronically fitted with pancreatic accessory duct cannulas and 2 duodenal cannulas to provide precise measurement, sampling, and reintroduction of pancreatic juice as well as additional infusions. Animals were fed milk formula based on skim milk powder or soybean concentrate. Level of deficiency depended on dietary protein origin. Twice as much protein or trypsin was required with a soybean concentrate diet than with a skim milk powder diet to obtain maximal nutrient digestibility. Pancreatic protein concentration in the juice can be used to differentiate between normal and deficient animals. Among these proteins, trypsin measurement is a good pancreatic deficiency marker. These results confirmed the major role of exocrine pancreatic secretions in producing optimal digestion in young calves. Furthermore, practical applications of these results can be applied for the young in other animal species and in humans.
\end{abstract}

Key words: pancreatic juice secretion, trypsin activity, dietary protein origin, digestibility

\section{INTRODUCTION}

The exocrine pancreas supplies the duodenum with several complementary components, including water and electrolytes (important for digesta dilution and optimal environment for bile acids and enzymatic degradation), enzymes and coenzymes (crucial for food con-

Received October 7, 2010

Accepted December 5, 2010.

${ }^{1}$ Corresponding author: Paul.Guilloteau@rennes.inra.fr, paul. guilloteau@gmail.com stituent breakdown), antibacterial proteins, hormones, and many other substances (Guilloteau and Zabielski, 2005). Pancreatic acinar cells are specialized in synthesis, storage, and secretion of large quantities of more than 2 dozen digestive enzymes (Stormon and Durie, 2002). Besides amylase, most pancreatic juice enzymes are secreted into the duodenum in an inactive form and following duodenal enterokinase or trypsin activation, can hydrolyze the majority of dietary components (proteins, carbohydrates, lipids, nucleic acids, among others). The mature exocrine pancreas seems to have large potentialities for digestive functions. DiMagno et al. (1973) showed that signs of fat maldigestion due to chronic pancreatitis in adults only occur when $90 \%$ of pancreatic reserves are lost. According to Stormon and Durie (2002) approximately 99\% of enzyme secretory capacity must be lost before manifestations of maldigestion become evident. In contrast to the adult, the juvenile pancreas seems to have lesser digestive capabilities and a higher demand for available nutrients. Consequently, a higher production of digestive enzymes to hydrolyze the diet components exists, which can be attributed to intensive body growth and tissue rebuilding (Zabielski et al., 1999). Pancreatic secretion (volume, protein and trypsin activity) in milk formula-fed calves shows clear interdigestive periodic oscillations (Zabielski et al., 1993). However, in response to food intake, unlike in adult dogs and humans, it shows a biphasic pattern (i.e., a short-lasting elevation followed by a longer lasting 1- to 2-h decrease; Le Dréan et al., 1997), indicating that the secretory capacity of the juvenile pancreas is low and presumably may limit food digestibility. Importantly, postprandial decrease was more evident in calves fed milk replacer based on soybean protein than in those fed milk powder (Le Drean et al. 1998). Furthermore, Botermans and Pierzynowski (1999) have demonstrated a close relationship between performance and activity of trypsin secreted in pancreatic juice in weaned pigs.

Several studies have tried to evaluate the role of pancreatic enzymes in total digestion by measuring apparent fecal digestibility in young and adult animals following pancreatic duct ligation (Uram et al., 1960; 
Table 1. Composition of milk formulas

\begin{tabular}{lcc}
\hline Item & $\begin{array}{c}\text { Milk diet } \\
\text { (M diet) }\end{array}$ & $\begin{array}{c}\text { Soybean diet } \\
\text { (SB diet) }\end{array}$ \\
\hline Ingredient (\%) $^{1}$ Fats $^{1}$ & & \\
Skim milk powder $_{\text {Whey powder }}$ & 21.2 & 19.4 \\
Whey protein concentrate & 57 & - \\
Pregelatinized starch $^{2}$ & 13.6 & 38.8 \\
Soybean concentrate & - & 2.3 \\
Lactose & 3.7 & 2 \\
Minerals, trace elements, vitamins, and synthetic amino acids ${ }^{3}$ & - & 24.5 \\
Chemical composition analysis (\% of DM) & - & 9 \\
Proteins (N $\times$ 6.25) & 4.5 & 4 \\
Fat & & 21.1 \\
N-free extract & 22.2 & 21.1 \\
Ash & 20.6 & 49.4 \\
Ca & 49.9 & 8.4 \\
P & 7.3 & 1.05 \\
\hline
\end{tabular}

${ }^{1}$ Tallow (78\%) and coconut oil (22\%).

${ }^{2}$ Contained $70 \mathrm{~g}$ of protein/100 g of DM and was prepared from dehulled soybeans by hexane extraction of oil and hot aqueous ethanol extraction of sucrose and $\alpha$-galactosides.

${ }^{3}$ For all the characteristics concerning minerals, trace elements, vitamins, and synthetic amino acids, see Le Dréan et al. (1997).

Pekas et al., 1964; Corring and Bourdon, 1977; Simoes Nunes et al., 1981). This approach, however, raises the possibility of adaptation of gastric and intestinal mucosa and, presumably, microbial digestive function after duct ligation. On the other hand, studies in pancreatic duct-cannulated animals with controlled flow of pancreatic juice into the duodenum generate data free of such artifacts and produce more reliable results. The present study was conducted in artificial milk formula-fed calves chronically fitted with a pancreatic duct catheter. It evaluated apparent fecal digestibility in calves under different pancreatic juice supply. Milk formula was based either on skim milk powder or soybean protein to evaluate the influence of protein origin. The aim of this study was to test the hypothesis that utilization by milk-fed calves of dietary proteins derived from soybeans is less efficient than with milk proteins, due to pancreatic deficiency under physiological conditions.

\section{MATERIALS AND METHODS}

\section{Animal, Diets, and Feeding}

Treatments and experiments were conducted according to European Union regulations concerning protection of experimental animals. Ten Holstein-Friesian male calves were born clinically healthy and were given colostrum $(25 \mathrm{~g} / \mathrm{kg}$ of BW per meal) during the first $2 \mathrm{~d}$ of life, and then received a milk formula based on skim milk powder, whey powder, and tallow ( $\mathbf{M}$ diet). From d 56, the calves were fed either the M diet or a milk formula based on an alcohol-extract soybean concentrate $(76.6 \%)$ and whey powder (SB diet), the composition of which is shown in Table 1. Soybean protein was chosen in this experiment, as it is the most common substitute for natural milk proteins in milk replacers for rearing calves. In the SB diet, antitryptic activity was very low $(0.07 \%$ of that found in raw soybean) and antigenic activity and other antinutritional factors, such as lectins, were not detected. Calves were fed twice daily at 0830 and $1630 \mathrm{~h}$. The DMI was 66 $\mathrm{g} / \mathrm{d}$ per $\mathrm{kg}$ of $\mathrm{BW}^{0.75}$. Diets were sampled during the study and stored for analysis.

\section{Experimental Design and Calf Management}

At about $40 \mathrm{~d}$ of age, each calf was surgically fitted with 3 permanent cannulas (one in the pancreatic accessory duct and 2 in the duodenum) under halothane anesthesia (Le Dréan et al., 1997). After surgery, calves received routine antibiotic and treatment with an analgesic. Pancreatic juice was routinely collected, measured for volume and reintroduced into the duodenum by means of an automatic servo-mechanism starting on the third day post surgery. A constant proportion of the juice $(8 \%)$ was sampled at 15-min intervals, and transferred into a fraction collector at $4^{\circ} \mathrm{C}$. The aliquots were then frozen and stored at $-20^{\circ} \mathrm{C}$ until analysis.

Digestibility and pancreatic studies were carried out between d 63 and 130 of life (Figure 1). Calves were kept in metal crates. Feces were collected each day during each experimental treatment and representative aliquots were frozen before subsequent freeze-drying 
and analysis. At d 56, calves were randomly allocated either an $\mathrm{M}$ or SB diet, and a series of digestibility/ juice collection studies was performed. Next, on d 82 or 89 (Figure 1), the diets were switched and the protocol repeated, and the animals that started on the $\mathrm{SB}$ diet were fed the $\mathrm{M}$ diet and vice versa. In each series (M and SB), digestibility/juice collection studies were performed with a 0,50 , and $92 \%$ reintroduction of actually secreted pancreatic juice quantity. Additionally, a $184 \%$ reintroduction treatment was studied (only with SB diet) using a pool of pancreatic juice saved during earlier treatments (with 0 and $50 \%$ reintroduction). Each calf received its own pancreatic secretion, which was stored frozen $\left(-20^{\circ} \mathrm{C}\right)$ and reheated $\left(+35^{\circ} \mathrm{C}\right)$ just before reinfusion. To summarize, each animal was subjected to 7 treatments in a Latin square design: 3 levels of reintroduction with $\mathrm{M}$ diet $(0,50$, and $92 \%)$, and 4 levels with SB diet $(0,50,92$, and $184 \%)$, each treatment lasting for $4 \mathrm{~d}$ (Figure 1). When switching the treatments, $3 \mathrm{~d}$ were allocated for the calf to adapt to the new treatment and when switching the diets, 4 supplementary days were allocated for diet transition; thus, it took a total of $7 \mathrm{~d}$ to change the diet. Our previous observations (Le Drean et al., 1998) have shown that one treatment did not influence the next treatment for the parameters measured. Treatment with $92 \%$ reintroduction was considered the control, because

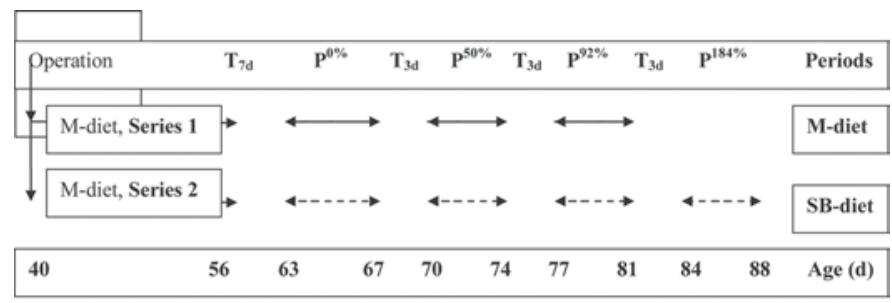

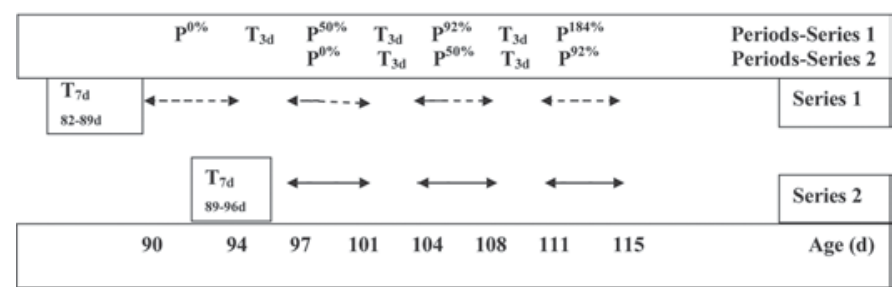

Figure 1. Theoretical schema of experimental protocols: milk diet (M diet; arrows with solid line) or soybean diet (SB diet; arrows with dashed line); $\mathrm{P}^{0 \%}, \mathrm{P}^{50 \%}, \mathrm{P}^{92 \%}$, and $\mathrm{P}^{184 \%}$ indicate digestibility/juice collection periods that were performed with $0,50,92$, and $184 \%$ reintroduction of pancreatic trypsin, respectively (4 treatments); Series 1 and Series 2 indicate 2 groups of animals fed the $\mathrm{M}$ diet or SB diet during the first period of measurements, respectively. In each series, the succession of digestibility/juice collection period was changed when the animals were fed the same diet to obtain a Latin square as experimental design. $\mathrm{T}_{7 \mathrm{~d}}$ and $\mathrm{T}_{3 \mathrm{~d}}$ indicate duration of transition between the 2 milk formulas $(7 \mathrm{~d})$ and between 2 treatments (3d), respectively. previous studies in calves showed that a decrease of $8 \%$ pancreatic juice is negligible for the feedback regulation (Le Dréan et al., 1997).

\section{Laboratory and Statistical Analyses}

Diets and feces were analyzed for DM, N, and fat content according to methods described previously (Branco-Pardal et al., 1995). Pancreatic juice was analyzed for total protein (Lowry et al., 1951) and trypsin (EC 3.4.21.1) activity as described by Lainé et al. (1993). The enzyme activity was expressed in IU per $\mathrm{mL}$ of juice, per mg of pancreatic proteins (specific activity), or per $\mathrm{kg}$ of BW. Trypsin was selected from the pancreatic enzymes because it is a proteolytic enzyme that modifies the protein of dietary origin (soybean vs. milk).

Data are shown as means and standard error of the means, except in the figures. The Newman-Keuls test was used to assess the effects of diet and treatment, which were considered significant at $P<0.05$ (tendencies were reported when $0.05<P<0.10$ ). The effect of age was not taken into account in the statistical analysis because large changes were observed before 1 mo of age. In contrast, very little variation exists in nutrient digestibility, pancreatic secretions relative to $\mathrm{BW}$, and digestion regulation after $1.5 \mathrm{mo}$ of age in milk-fed calves (Guilloteau et al., 2010a).

\section{RESULTS}

Calves remained clinically healthy during the study and relative growth was within normal range for cannulated animals (Table 2). Five calves did not follow the entire digestibility/juice collection protocol due to accidental removal of indwelling cannulas or difficulties in maintaining pancreatic catheter function. Therefore, due to technical problems, not all calves could be fully studied. Calves were slaughtered at the end of the experiment. Postmortem examination of the upper gastrointestinal tract did not show pathological changes near implanted cannulas besides minor distension of the pancreatic accessory duct. The main pancreatic duct was either not present or was present but did not function in examined calves.

\section{Digestibility and Pancreatic Secretion in Control Treatments}

Under control conditions (92\% juice reintroduced), calves that were fed the SB diet showed significantly lower daily growth $(P<0.05)$ when compared with the $\mathrm{M}$ diet (Table 2). Apparent fecal digestibility of the SM diet was also lower for DM, N, and fat when 
Table 2. Growth rate, nutrient digestibility, and pancreatic secretions in calves fed milk formula containing milk or soybean proteins under control conditions ( $92 \%$ of pancreatic juice reintroduced $)^{1}$

\begin{tabular}{lccc}
\hline & \multicolumn{2}{c}{ Diet } & \\
\cline { 2 - 3 } Item & Milk & Soybean & SEM \\
\hline Calf (n) & 7 & 7 & - \\
Daily gain (g/d) & $1,374^{\mathrm{a}}$ & $1,189^{\mathrm{b}}$ & 85 \\
Digestibility (\%) & & & \\
DM & $96.1^{\mathrm{a}}$ & $84.5^{\mathrm{b}}$ & 1 \\
Nitrogen & $94.5^{\mathrm{a}}$ & $74.3^{\mathrm{b}}$ & 2.5 \\
Fat & $92.6^{\mathrm{a}}$ & $74.9^{\mathrm{b}}$ & 3.2 \\
Juice content & & & 0.9 \\
Protein (g/mL) & $5.6^{\mathrm{a}}$ & $6.1^{\mathrm{a}}$ & 0.38 \\
Trypsin (IU/mL) & $2.67^{\mathrm{a}}$ & $2.83^{\mathrm{a}}$ & 52 \\
Trypsin specific activity (IU/mg of protein) & $477^{\mathrm{a}}$ & $426^{\mathrm{a}}$ & 1 \\
Pancreatic secretion (/d per kg of BW) & $12.3^{\mathrm{a}}$ & $11.2^{\mathrm{a}}$ & 7 \\
Juice (mL) & $62.0^{\mathrm{a}}$ & $65.0^{\mathrm{a}}$ & 3.2 \\
Proteins (mg) & $28.1^{\mathrm{a}}$ & $30.8^{\mathrm{a}}$ & \\
Trypsin (IU) & & \\
\hline
\end{tabular}

${ }^{\mathrm{a}, \mathrm{b}}$ Within a row, means without a common superscript letter differ $(P<0.05)$.

${ }^{1}$ Data are means \pm SEM.

compared with that of the $\mathrm{M}$ diet $(P<0.05)$. Daily pancreatic juice secretion relative to BW was similar for both diets. Protein and trypsin concentrations in pancreatic secretions, as well as secreted quantities, were not modified by diet (Table 2 ).

\section{Effect of Pancreatic Protein and Trypsin Reintroduction}

Compared with control conditions (92\% pancreatic juice reintroduced), when pancreatic secretion was not reintroduced (total diversion), DM digestibility was significantly decreased by $21 \%$ for the $\mathrm{M}$ diet, and by $23 \%$ for the SB diet (Tables 2 and 3 ). The corresponding fat digestibility was decreased by 46 and $55 \%$, and nitrogen digestibility by 47 and $75 \%$, respectively (all $P$ $<0.05$ ). The decrease in nitrogen digestibility was more important with the SB diet than with the $\mathrm{M} \operatorname{diet}(P<$ 0.05) (Tables 2 and 3).
Samples were kept and analyzed later, as it was not possible to assess the composition of secreted pancreatic juice during collection in real time. Great individual variation in composition of pancreatic juice existed. Moreover, for 5 of the 10 calves used, it was not possible to follow the experimental design because 7 treatments were not applied to each calf (see Materials and Methods). In light of these observations, it was difficult to examine the data as foreseen in the experimental design [i.e., a Latin square design based on the quantity of pancreatic juice reintroduced into the duodenum $(0$, 50,92 , and $184 \%$ of secreted quantities)]. Therefore, within each diet, all data obtained in each period were combined to examine the variation of apparent nutrient digestibility in relation to the quantity of proteins reintroduced into the duodenal lumen (measured a posteriori), as shown in Figure 2, for DM with $\mathrm{M}$ and SB diets. When pancreatic protein quantity increased from 0 , nutrient digestibility increased to a maximal

Table 3. Apparent fecal digestibility (\%) of nutrients when no pancreatic juice was reintroduced into the duodenum or to obtain the maximal digestibility whatever the level of reintroduction ${ }^{1}$

\begin{tabular}{lccc}
\hline & \multicolumn{3}{c}{ Diet } \\
\cline { 2 - 3 } Item $^{2}$ & Milk & Soybean & SEM \\
\hline Digestibility without pancreatic juice & $\mathrm{n}=6$ & $\mathrm{n}=7$ & \\
DM & 76.5 & 65.9 & 2.6 \\
$\mathrm{~N}$ & 50.9 & 18.8 & 6.1 \\
Fat & 50.9 & 33.9 & 5.6 \\
Maximal digestibility obtained whatever the level of reintroduction & $\mathrm{n}=12$ & $\mathrm{n}=14$ & \\
DM & 94.5 & 83.6 & 1.3 \\
N & 91.6 & 71.4 & 2.7 \\
Fat & 90.2 & 72.4 & 2.5 \\
\hline
\end{tabular}

${ }^{1}$ Data are means \pm SEM.

${ }^{2}$ For each nutrient, the values obtained under same conditions with milk and soybean diets are different $(P<$ $0.05)$. 
Milk diet

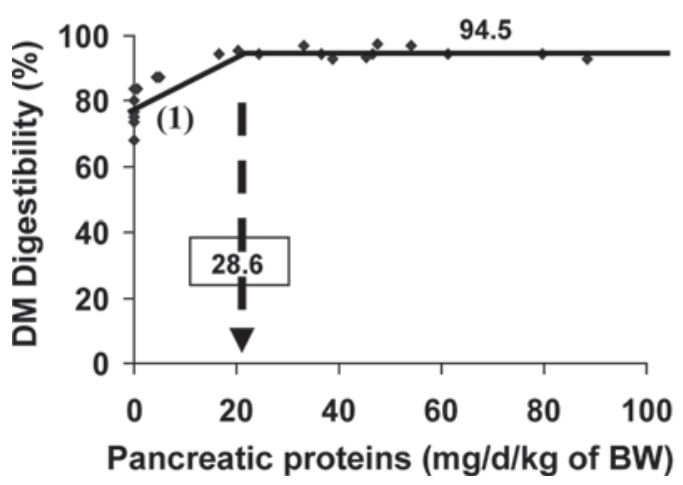

Soybean diet

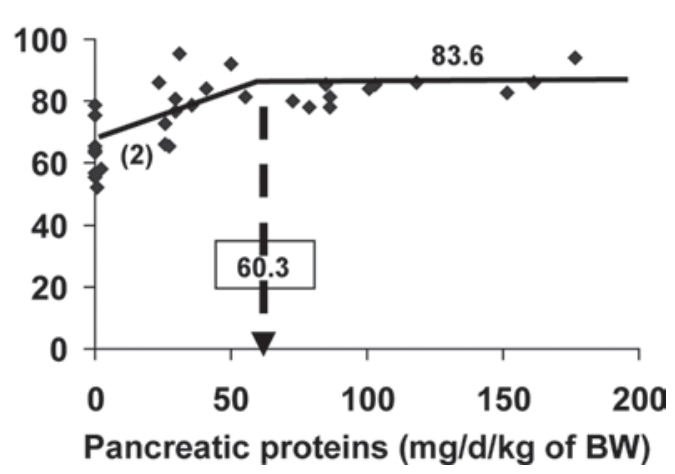

Figure 2. Dry matter digestibility (\%) dependent on pancreatic protein quantity reintroduced into the duodenum (mg/d per kg of BW). For each diet, the minimal protein quantity necessary to have maximal DM digestibility is calculated. (For each diet, each point represents the result obtained during one treatment in the 7 treated calves; see Materials and Methods). For the milk diet, $\mathrm{DM}$ digestibility $=0.571 \mathrm{P}+79.34\left(\mathrm{R}^{2}=\right.$ $0.68, P<0.05)$ and for the soybean diet, $\mathrm{DM}$ digestibility $=0.529 \mathrm{P}+62.89\left(\mathrm{R}^{2}=0.52, P<0.05\right)$, where $\mathrm{P}=$ protein $(\mathrm{cf}$. Table 4$)$. The number in the box indicates the quantity of proteins reintroduced into the duodenum $(\mathrm{mg} / \mathrm{d}$ per $\mathrm{kg}$ of $\mathrm{BW})$ to obtain maximal digestibility.

value, which was not modified by additional pancreatic proteins reintroduced into the duodenum. This led to the hypothesis, and then the verification, that this evolution is best represented by a linear relation (Figure 2, Table 4).Thus, when the maximal value was reached or the mean value obtained, regardless of introduction of additional quantities of pancreatic proteins, the measured digestibility in normal calves was demonstrated (horizontal line in Figure 2). The intersection between the 2 lines corresponds to the minimal level of pancre- atic protein necessary to obtain the maximal digestibility. A similar procedure was applied for nitrogen and fat from values obtained with $\mathrm{M}$ and SB diets (Figure 3, Table 4).

A similar approach was also examined with the quantity of trypsin reintroduced into the duodenal lumen. Pancreatic juice proenzymes (such as trypsinogen) were infused because the juice was not activated. When the activity in pancreatic juice samples was measured, trypsinogen was activated (see methods). Thus, all data

Table 4. Relationships obtained for each nutrient from each diet, between digestibility and pancreatic secretions reintroduced into the duodenum to reach the maximal value of digestibility ${ }^{1}$

\begin{tabular}{|c|c|c|c|c|}
\hline Item & Relationship ${ }^{2}$ & $\begin{array}{c}\text { Correlation } \\
\left(\mathrm{R}^{2}\right)\end{array}$ & \multicolumn{2}{|c|}{ Calculation of minimal pancreatic secretion } \\
\hline \multicolumn{5}{|c|}{ Pancreatic proteins $(\mathrm{P}, \mathrm{mg})$} \\
\hline DM & $\mathrm{y}=0.571 \mathrm{P}+79.34$ & 0.68 & 27.1 & \multirow{3}{*}{28.6} \\
\hline $\mathrm{N}$ & $\mathrm{y}=1.194 \mathrm{P}+56.81$ & 0.63 & 29.5 & \\
\hline Fat & $\mathrm{y}=1.200 \mathrm{P}+56.97$ & 0.63 & 29.1 & \\
\hline $\mathrm{N}$ & $\mathrm{y}=1.352 \mathrm{P}+15.88$ & 0.75 & 61.3 & \multirow[t]{2}{*}{60.3} \\
\hline Fat & $\mathrm{y}=1.100 \mathrm{P}+29.69$ & 0.47 & 59.7 & \\
\hline \multicolumn{5}{|c|}{ Pancreatic trypsin $(\mathrm{T}, \mathrm{IU})$} \\
\hline \multicolumn{5}{|c|}{ Milk diet $(\mathrm{n}=14)$} \\
\hline $\mathrm{DM}$ & $\mathrm{y}=1.002 \mathrm{~T}+79.93$ & 0.48 & 14.2 & \multirow{3}{*}{13.4} \\
\hline $\mathrm{N}$ & $\mathrm{y}=2.361 \mathrm{~T}+58.49$ & 0.52 & 13.8 & \\
\hline Fat & $\mathrm{y}=2.408 \mathrm{~T}+58.90$ & 0.51 & 12.1 & \\
\hline
\end{tabular}

${ }^{1}$ Calculations are based on quantity reintroduced. $\mathrm{P}$ or $\mathrm{T}$ are expressed as quantities from 0 to maximal value for digestibility; $\mathrm{y}=$ digestibility of the corresponding nutrient (from 0 to maximal value).

${ }^{2}$ It was hypothesized and then verified that the relationship was linear $(P<0.05)$.

${ }^{3}$ This calculated value represents minimal pancreatic secretion $(\mathrm{P}$ or $\mathrm{T})$ necessary to obtain maximal digestibility value. 

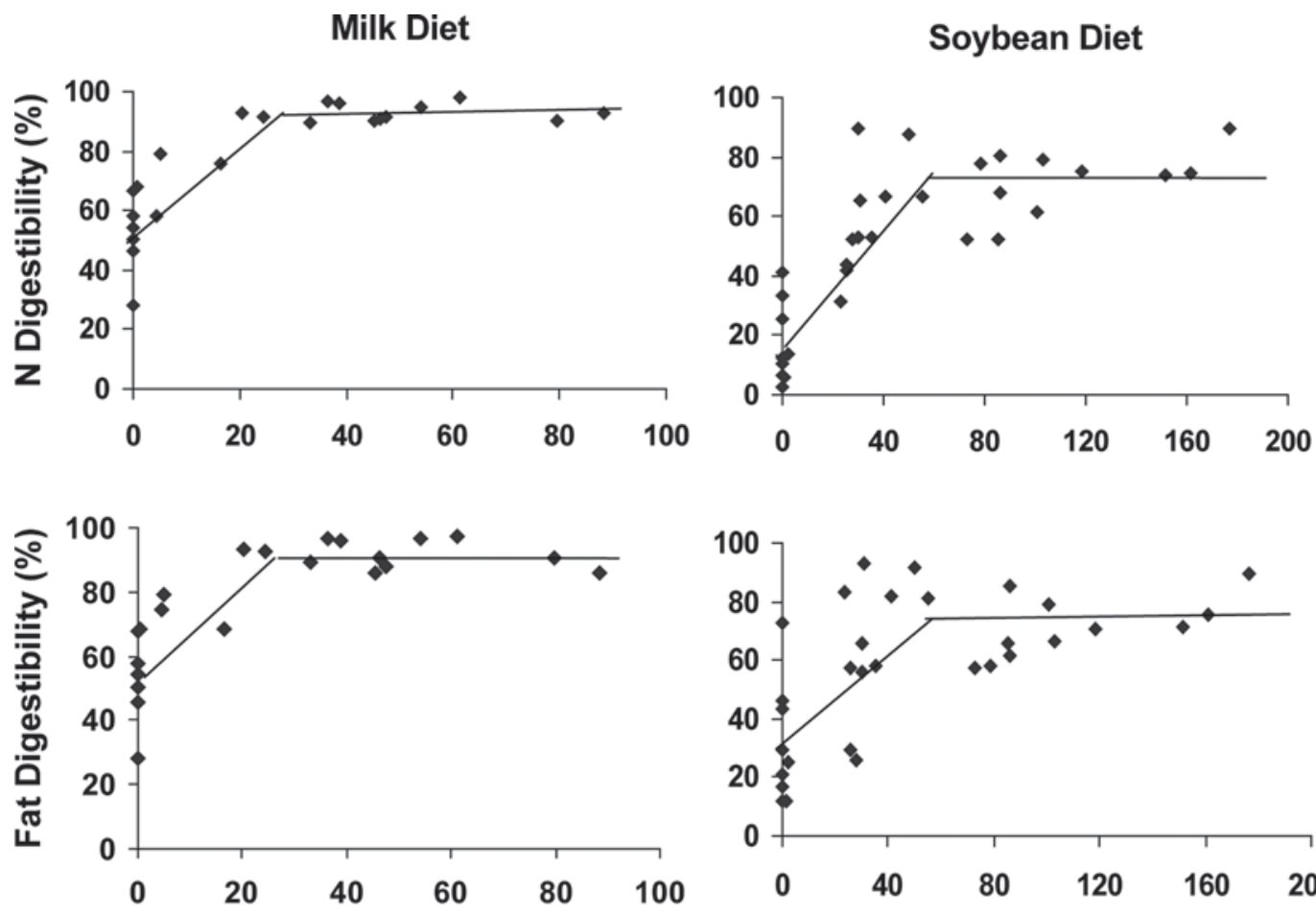

Pancreatic proteins $(\mathrm{mg} / \mathrm{kg}$ of BW)

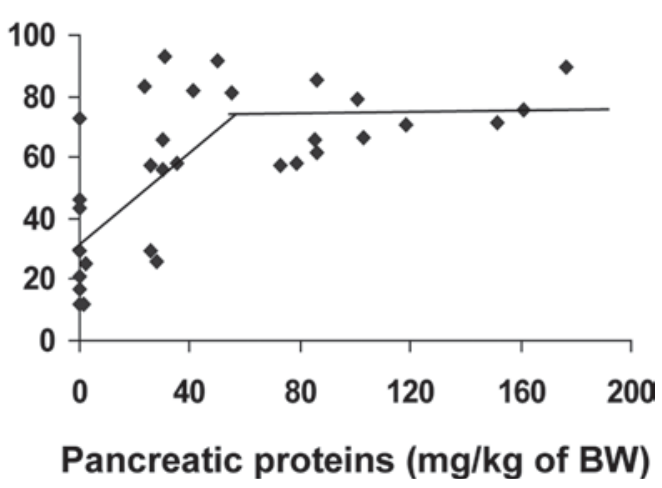

Figure 3. Nitrogen and fat digestibility (\%), dependent on pancreatic protein quantity reintroduced into the duodenum (mg/d per $\mathrm{kg}$ of BW) for each diet. (For each diet, each point represents the result obtained during one treatment in the 7 treated calves; see Materials and Methods).

are expressed as IU of trypsin activity to represent an estimation of trypsin quantities. The effects of the level of pancreatic trypsin reintroduced into the duodenum are considered as exposed to reintroduced pancreatic proteins for DM, N, and fats for values obtained (Figure 4) with $\mathrm{M}$ and SB diets.

The maximal digestibility value (Table 3 ) was similar to the value obtained in this experiment with the control treatment (Table 2) for each nutrient and for each diet. Thus, with the SB diet, these values (for experiment-level reintroduction treatment and control treatment, respectively) were $83.6 \pm 1.3 \%(\mathrm{n}=14)$ and $84.5 \pm 2.0 \%(\mathrm{n}=7)$ for $\mathrm{DM}(\mathrm{NS})$, and $71.7 \pm 3.0 \%(\mathrm{n}$ $=14)$ and $74.3 \pm 4.6 \%(\mathrm{n}=7)$ for nitrogen (NS). With the SB diet, it was necessary to double protein (60.3 vs. $28.6 \mathrm{mg} / \mathrm{d}$ per $\mathrm{kg}$ of BW) or trypsin (25.5 vs. $13.4 \mathrm{IU} / \mathrm{d}$ per $\mathrm{kg}$ of BW) quantities as compared with the M diet, to obtain the maximal nutrient digestibility (Table 4).

\section{DISCUSSION}

Calves fitted with permanent cannulas in their pancreatic duct were used to evaluate if a relative deficiency in the secretion of pancreatic protein and trypsin exists in preruminant calves fed diets of different composition.
This approach allowed the study of the secretion of pancreatic juice, as well as the analysis of its quantity and components (total proteins and trypsin activity), in real time as it was secreted into the duodenum in response to different feedings, and, therefore, was an improvement compared with a one-point analysis study of pancreas tissue content measured after slaughter (Le Dréan et al., 1995). Animals in our study were fed a milk formula based on 2 different protein sources (milk powder or soybean concentrate) and apparent digestibility of nutrients was measured in relation to the amount of pancreatic protein (or trypsin) reintroduced into the duodenum. This unique study design allowed us to estimate the minimal pancreatic protein (and trypsin) secretion that is necessary to obtain maximal nutrient digestibility in milk-fed calves. To date, this is the first attempt to estimate the secretory capacity of the juvenile pancreas in the bovine species to digest nutrients in physiological conditions.

Overall, the results obtained for maximal digestibility values in calves fed the $\mathrm{M}$ diet under control conditions (92\% juice reintroduced) corroborate with previous data on digestibility (Toullec and Lallès, 1995; Guilloteau and Zabielski, 2005) and pancreatic secretion (Le Dréan et al., 1997, 1998). In calves, therefore, 
Milk Diet
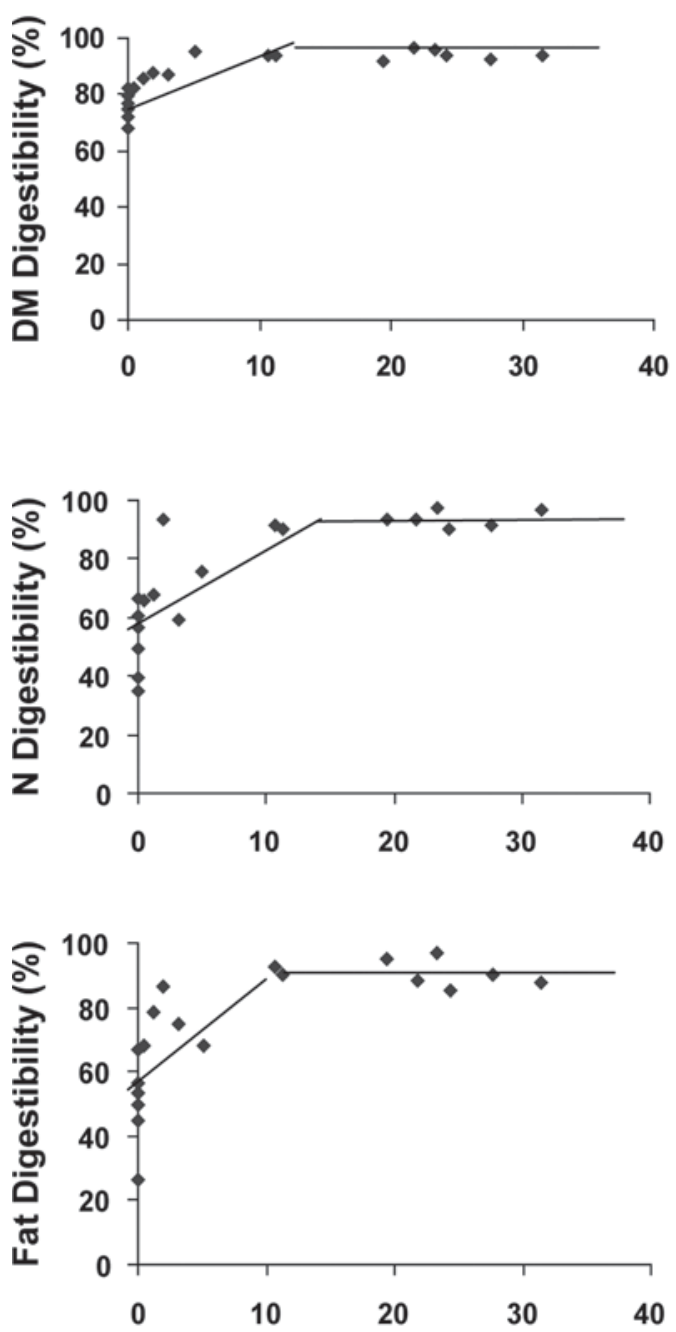

Pancreatic trypsin $(\mu \mathrm{mol} / \mathrm{d} / \mathrm{kg}$ of BW)
Soybean Diet
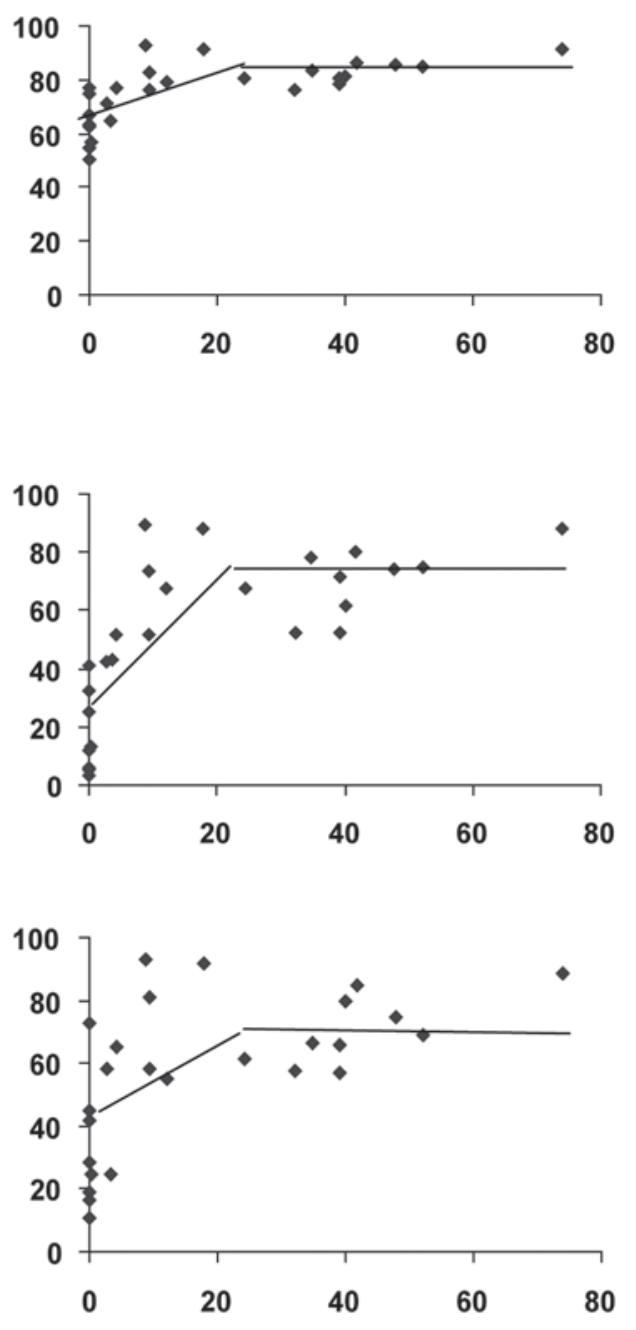

Pancreatic trypsin $(\mu \mathrm{mol} / \mathrm{d} / \mathrm{kg}$ of BW)

Figure 4. Digestibility (\%) of DM, nitrogen, and fats, dependent on the quantity of pancreatic trypsin reintroduced into the duodenum $(\mathrm{mg} / \mathrm{d}$ per $\mathrm{kg}$ of $\mathrm{BW})$ for each diet. (For each diet, each point represents the result obtained during one treatment in the 7 treated calves; see Materials and Methods).

the digestive contribution of pancreatic secretions seems to be more important than that obtained from the gastric secretions. Thus, stomach bypass decreased apparent protein digestibility by only $2 \%$ (Guilloteau et al., 1981) in contrast to a $44 \%$ decrease obtained after total diversion of pancreatic juice in the present study. In these 2 calf studies, a similar milk formula based on milk powder was used. The role of the pancreas in food digestion was previously estimated in several mammalian species with pancreatic duct ligation (Uram et al., 1960; Pekas et al., 1964; Corring and Bourdon, 1977; Simoes Nunes et al., 1981). In piglets, 2 wk after ligation, the decrease in digestibility of milk protein was similar to that observed in the calves, but that of soybean protein was even more diminished (Pekas et al., 1964). However, in ligation studies, the digestibility increased with time, probably due to compensation of digestive processes (Corring and Bourdon, 1977) or adaptation of controlling mechanisms (Corring et al., 1985) in the stomach and intestine. Moreover, this study established the minimal daily amount of pancreatic protein secretion into the duodenum needed to achieve maximal digestibility in relation to dietary protein origin. Under these conditions, this critical amount of protein secretion that is necessary to digest the soybean diet was approximately twice as high as that needed to digest the milk diet. This result is probably due to the fact that, first, soybean protein is more resis- 
tant to enzyme degradation when compared with milk protein (Guilloteau and Zabielski, 2005), and, second, that postprandial gastric digesta flow rate is higher if a diet contains soybean protein than if a milk protein forms the basis of diet (Guilloteau et al., 1979), and, third, the kinetics of postprandial pancreatic secretion are different in response to each diet (Le Drean et al., 1998; Guilloteau and Zabielski, 2005). Previous studies also demonstrated apparently different patterns of gut motility and regulatory peptides in circulating blood according to protein source of milk replacer formula (Zabielski et al., 1998). This is in agreement with the slow (milk) and fast (soybean) dietary protein digestion in the calf (Guilloteau et al., 1979; 1981) and humans (Boirie et al., 1997). Our data suggest that the large difference between the 2 diets in minimal pancreatic protein secretion (28.6 vs. $60.3 \mathrm{mg} / \mathrm{d}$ per $\mathrm{kg}$ of BW, cf. Table 3), which is needed to obtain normal digestion, is chiefly due to the nature of dietary protein source. Furthermore, the nature of dietary proteins affected not only protein digestion, but also that of the other components of the diet. These results confirm previous observations in calves showing that fat digestibility decreases in parallel to nitrogen digestibility when animals are fed milk formula based on milk proteins or protein substitutes (Guilloteau et al., 1986; Lallès and Toullec, 1998). This observation is also in agreement with the fact that single-enzyme deficiencies are very rare (Stormon and Durie, 2002). Based on similar dependency of digestibility on pancreatic protein level and trypsin activity, it is suggested that the immunoreactivity of trypsin in the gut lumen can be used as a marker of pancreatic reserve or deficiency.

In young production animals, and presumably in young mammals in general, it may be necessary to revise the concept of pancreatic deficiency. According to the present study, less than one-third of secreted pancreatic enzymes are necessary to digest proteins of milk origin in the small intestine, whereas the remaining two-thirds of secretion can be considered as a functional reserve. Evidently, pancreatic secretion is not a factor limiting milk protein digestibility. However, feeding soybean protein resulted in a marked decrease of the functional reserve and might cause temporary deficiency in the circadian secretion of pancreatic enzymes. Doubling the secretion did not improve the digestibility of soybean protein. This result is somewhat surprising, as in adult human subjects with pancreatic enzyme deficiency, the administration of extra pancreatic enzymes is effective and corrects maldigestion, loss of $\mathrm{BW}$, and the decreased nutritional status (Pap and Marosi, 1992; Ghaneh and Neoptolemos, 1999; Littlewood et al., 2006; Domínguez-Muñoz, 2007) although more developments are needed to optimize treatments (Keller and
Layer, 2003). In contrast, the situation seems to be very different in human infants. In humans, the exocrine pancreas is not mature at birth and development of pancreatic function, including that of digestive enzymes (and particularly trypsin), takes place during childhood (Guilloteau et al., 2010b). During this period, pancreatic enzyme deficiencies appeared to be more prevalent when diets containing proteins with low digestibility were used. Particular attention, therefore, should be directed to the young in this field. Studies in calves are lacking, but this discrepancy may be explained by the composition of pancreatic enzymes (i.e., presence of different enzyme isoforms; Pierzynowski et al., 1990) in milk formula fed calves not matching protein other than those of milk origin.

Finally, in this work, we have demonstrated that pancreatic deficiency may exist, in particular when a non-milk protein is ingested. The deficiency can be detected by the amount of secreted protein (or pancreatic trypsin) rather than the juice volume. Taken together, these results confirmed the importance of pancreatic enzyme secretion to obtain optimal digestion in calves, and presumably demonstrate a more universal pattern characteristic for juvenile mammals.

In conclusion, the juvenile pancreas secretes enough pancreatic enzymes to digest milk proteins efficiently and guarantee the physiological functional reserve, but when the source of protein is changed, the functional reserve can be markedly limited. This aspect can be classified as acquired disorders, in which loss of pancreatic function is a secondary phenomenon and is due to nutritional factors. Practical applications of these results may be possible in animal species and humans. Thus, in the case of pancreatic exocrine insufficiency, the first treatment that could be suggested is based on nutritional recommendations encompassing diet components readily digested by pancreatic enzymes (like milk proteins for the nitrogen component). Such a recommendation may also be appropriate for human infants because their pancreatic enzyme system is not sufficiently developed.

\section{ACKNOWLEDGMENTS}

This work was co-financed by the grants obtained within the frame of Polonium Program ( $\left.\mathrm{N}^{\circ} 13968 \mathrm{PE}\right)$. The authors greatly acknowledge J. H. Burton (University of Guelph, Guelph, Canada) and Victoria Frances O'Gorman (Warsaw University of Life Sciences, Warsaw, Poland) for the English revision of the manuscript.

\section{REFERENCES}

Boirie, Y., M. Dangin, P. Gachon, M.-P. Vasson, J.-L. Maubois, and B. Beaufrère. 1997. Slow and fast dietary proteins differently modu- 
late postprandial protein accretion. Proc. Natl. Acad. Sci. USA 94:14930-14935.

Botermans, J. A., and S. G. Pierzynowski. 1999. Relations between body weight, feed intake, daily weight gain, and exocrine pancreatic secretion in chronically catheterized growing pigs. J. Anim. Sci. 77:450-456.

Branco-Pardal, P., J. P. Lallès, M. Formal, P. Guilloteau, and R. Toullec. 1995. Digestion of wheat gluten and potato protein by the preruminant calf: Digestibility, amino acid composition and immunoreactive proteins in ileal digesta. Reprod. Nutr. Dev. 35:639-654.

Corring, T., and D. Bourdon. 1977. Exclusion of pancreatic exocrine secretion from intestine in the pig: Existence of a digestive compensation. J. Nutr. 107:1216-1221.

Corring, T., J. A. Chayvialle, C. Simoes-Nunes, and J. Abello. 1985. Regulation of pancreatic secretion by negative feedback and blood gastrointestinal hormones in the pig. Reprod. Nutr. Dev. 25:439450 .

DiMagno, E. P., V. L. Go, and W. H. Summerskill. 1973. Relations between pancreatic enzyme outputs and malabsorption in severe pancreatic insufficiency. N. Engl. J. Med. 288:813-815.

Domínguez-Muñoz, J. E. 2007. Pancreatic enzyme therapy for pancreatic exocrine insufficiency. Curr. Gastroenterol. Rep. 9:116-122.

Ghaneh, P., and J. P. Neoptolemos. 1999. Exocrine pancreatic function following pancreatectomy. Ann. N. Y. Acad. Sci. 880:308-318.

Guilloteau, P., G. Savary, Y. Jaguelin-Peyrault, V. Romé, L. Le Normand, and R. Zabielski. 2010a. Dietary sodium butyrate supplementation increases digestibility and pancreatic secretion in young milk-fed calves. J. Dairy Sci. 93:5842-5850.

Guilloteau, P., R. Toullec, J. F. Grongnet, P. Patureau-Mirand, J. Prugnaud, and D. Sauvant. 1986. Digestion of milk, fish and soyabean protein in the preruminant calf: Flow of digesta, apparent digestibility at the end of the ileum and amino acid composition of ileal digesta. Br. J. Nutr. 55:571-592.

Guilloteau, P., R. Toullec, P. Patureau-Mirand, and J. Prugnaud. 1981. Importance of the abomasum in digestion in the preruminant calf. Reprod. Nutr. Dev. 21:885-899.

Guilloteau, P., R. Toullec, D. Sauvant, and J. L. Paruelle. 1979. Utilization of proteins by the preruminant veal calf. VII.-Influence of replacing milk protein by soya bean or field-bean proteins on gastric emptying. Ann. Zootech. 28:1-17. (In French).

Guilloteau, P., and R. Zabielski. 2005. Digestive secretions in preruminant and ruminant calves and some aspects of their regulation. Page 159-189 in Calf and Heifer rearing. P. C. Garnsworthy, ed. Nottingham University Press, Nottingham, UK.

Guilloteau, P., R. Zabielski, H. M. Hammon, and C. C. Metges. 2010b. Nutrition programming of gastrointestinal tract development. Is the pig a good model for man? Nutr. Res. Rev. 23:4-22.

Keller, J., and P. Layer. 2003. Pancreatic enzyme supplementation therapy. Curr. Treat. Options Gastroenterol. 6:369-374.

Lainé, J., M. Beattie, and D. LeBel. 1993. Simultaneous kinetic determinations of lipase, chymotrypsin, trypsin, elastase, and amylase on the same microtiter plate. Pancreas 8:383-386.

Lallès, J. P., and R. Toullec. 1998. Soybean products in milk replacers for farm animals: Processing, digestion and adverse reactions. Recent Res. Dev. Agric. Food Chem. 2:565-576.
Le Dréan, G., I. Le Huërou-Luron, J. A. Chayvialle, V. PhilouzeRomé, M. Gestin, C. Bernard, R. Toullec, and P. Guilloteau. 1997. Kinetics of pancreatic exocrine secretion and plasma gut regulatory peptide release in response to feeding in preruminant and ruminant calves. Comp. Biochem. Physiol. Physiol. A Physiol. $117: 245-255$

Le Drean, G., I. Le Huerou-Luron, M. Gestin, V. Rome, M. Plodari, C. Bernard, J. A. Chayvialle, and P. Guilloteau. 1998. Comparison of the kinetics of pancreatic secretion and gut regulatory peptides in the plasma of preruminant calves fed milk or soybean protein. J. Dairy Sci. 81:1313-1321.

Le Dréan, G., I. Le Huërou-Luron, V. Philouze-Romé, R. Toullec, and P. Guilloteau. 1995. Response of the calf pancreas to differently processed soya bean and pea diets. Ann. Nutr. Metab. 39:164176.

Littlewood, J. M., S. P. Wolfe, and S. P. Conway. 2006. Diagnosis and treatment of intestinal malabsorption in cystic fibrosis. Pediatr. Pulmonol. 41:35-49.

Lowry, O. H., N. J. Rosebrough, A. L. Farr, and R. J. Randall. 1951. Protein measurement with the Folin phenol reagent. J. Biol. Chem. 193:265-275.

Pap, A., and E. Marosi. 1992. New trends in the treatment of exocrine pancreas deficiency. Orv. Hetil. 133:2885-2890. (In Hungarian).

Pekas, J. C., V. W. Hays, and A. M. Thompson. 1964. Exclusion of the exocrine pancreatic secretion: Effect on digestibility of soybean and milk protein by baby pigs at various ages. J. Nutr. $82: 277-286$.

Pierzynowski, S. G., B. R. Weström, J. Svendsen, and B. W. Karlsson. 1990. Development of the exocrine pancreas function in chronically cannulated pigs during 1-13 weeks of postnatal life. J. Pediatr. Gastroenterol. Nutr. 10:206-212.

Simoes Nunes, C., F. Lebas, and T. Corring. 1981. Apparent digestibility after ligature of the pancreatic duct in the growing rabbit: Effect of ad libitum feeding. Reprod. Nutr. Dev. 21:497-504. (In French).

Stormon, M. O., and P. R. Durie. 2002. Pathophysiologic basis of exocrine pancreatic dysfunction in childhood. J. Pediatr. Gastroenterol. Nutr. 35:8-21.

Toullec, R., and J. P. Lallès. 1995. Digestion dans la caillette et l'intestin grêle. Pages 387-394 in Nutrition des Ruminants Domestiques. R. Jarrige, Y. Ruckebusch, C. Demarquilly, M.H. Farce, and M. Journet, ed. INRA Editions, Paris, France. (In French)

Uram, J. A., L. Friedman, and O. L. Kline. 1960. Relation of pancreatic exocrine to nutrition of the rat. Am. J. Physiol. 199:387-394.

Zabielski, R., C. Dardillat, I. Le Huerou-Luron, C. Bernard, J. A. Chayvialle, and P. Guilloteau. 1998. Periodic fluctuations of gut regulatory peptides in phase with the duodenal migrating myoelectric complex in preruminant calves: Effect of different sources of dietary protein. Br. J. Nutr. 79:287-296.

Zabielski, R., I. Le Huërou-Luron, and P. Guilloteau. 1999. Development of gastrointestinal and pancreatic functions in mammalians (mainly bovine and porcine species): Influence of age and ingested food. Reprod. Nutr. Dev. 39:5-26.

Zabielski, R., T. Onaga, H. Mineo, and S. Kato. 1993. Periodic fluctuations in pancreatic secretion and duodenal motility investigated in neonatal calves. Exp. Physiol. 78:675-684 